\title{
Survival rate variation with different histological subtypes of poor prognostic male anal squamous cell carcinoma: a population-based study
}

\author{
Zihao Wan ${ }^{1, *}$, Zhihao Huang ${ }^{2, *}$, Vikash Vikash ${ }^{3, *}$, Kelash Rai ${ }^{4}$, Sindhu Vikash ${ }^{5}$, \\ Liaobin Chen ${ }^{1}$ and Jingfeng $\mathbf{L i}^{1}$ \\ ${ }^{1}$ Department of Orthopaedic Surgery, Zhongnan Hospital of Wuhan University, Wuhan, Hubei Province, China \\ ${ }^{2}$ Department of Colorectal and Anal Surgery, Zhongnan Hospital of Wuhan University, Wuhan, Hubei Province, China \\ ${ }^{3}$ Department of Gastroenterology, Renmin Hospital of Wuhan University, Wuhan, Hubei Province, China \\ ${ }^{4}$ Department of Medicine, Ziauddin Hospital, Karachi, Sindh, Pakistan \\ ${ }^{5}$ Department of Medicine, Chandka Medical College, Shaheed Mohtarma Benazir Bhutto Medical University, Larkana, Sindh, \\ Pakistan \\ *These authors have contributed equally to this work \\ Correspondence to: Zihao Wan, email: randomvan@163.com \\ Liaobin Chen, email: liaobinchen@163.com \\ Jingfeng Li, email: hbjfeng@163.com
}

Keywords: anus squamous cell carcinoma, male, tumor subtype, retrospective cohort study, SEER database

Received: March 26, $2017 \quad$ Accepted: August 17, $2017 \quad$ Published: September 16, 2017

Copyright: Wan et al. This is an open-access article distributed under the terms of the Creative Commons Attribution License 3.0 (CC BY 3.0), which permits unrestricted use, distribution, and reproduction in any medium, provided the original author and source are credited.

\section{ABSTRACT}

Background and objective: The prognosis of male anal squamous cell carcinoma (MASCC) and female anal squamous cell carcinoma (FASCC) is variable. The influence of tumor subtype on the survival rate and gender is poorly known. Our study is the largest population-based study and aims to outline the difference in survival between MASCC and FASCC patients.

Methods: A retrospective population-based study was performed to compare the disease-specific mortalities (DSMs) between genders related to the tumor subtypes. The Surveillance, Epidemiology, and End Results (SEER) program database was employed to obtain the data from January 1988 to December 2014.

Results: A total of 4,516, (3,249 males and 1,267 females), patients with anal squamous cell carcinomas (ASCC) were investigated. The 5-year DSMs were $24.18 \%$ and $\mathbf{1 8 . 0 8 \%}$ for men and women, respectively. The univariate analysis of the male basaloid squamous cell carcinoma (BSCC) and cloacogenic carcinoma (CC) patients demonstrated higher DSMs $(P<0.001)$. Moreover, in the multivariate analysis, BSCC and CC were associated with soaring DSMs in male patients $(P<0.05)$.

Conclusions: In the cohort of BSCC and CC patients, male patients demonstrated a considerable decrease in survival rate compared to females. A more precise classification of ASCC and individualized management for MASCC are warranted.

\section{INTRODUCTION}

Anal cancer is a relatively rare neoplasm, accounting for approximately $1 \%$ of the gastrointestinal cancers. The incidence rate has increased steadily over the last four decades, particularly in males [1-3]. Anal squamous cell carcinoma (ASCC) is the most common subtype and constitutes $90 \%$ of all the anal cancers [4]. Literature reports the significant difference in the prognostic factors, survival outcome, and biological behaviors of 
tumor in male patients from females [4-6]. Soeberg et al. [6] report that the women with ASCC have a better prognosis the men. Over the past few years, studies related to epidemiology and histological features have suggested that MASCC should not be considered as a common disease and called for the need of customized diagnostic and therapeutic strategies.

The survival and mortality rate of MASCC patients have significantly improved, in spite of a limited number of conventional management or clinical protocols [7]. To the best of our knowledge, neither randomized control trials have been conducted to identify the optimal therapy for MASCC nor any consensus has been reached to address the factors responsible for the disparity in survival rate between men and women with ASCC.

The primary purpose of this study was to investigate the influence of the tumor subtype on the prognosis of MASCC, which might help to improve the diagnostic and therapeutic strategies of ASCC. Data from the National Cancer Institute's Surveillance, Epidemiology, and End Results (SEER) program database was employed to determine the relationship of tumor subtype and prognosis by disease-specified mortality (DSM) for males and females suffering from ASCC. The National Cancer Institute does not require institutional review board approval for SEER studies because it is a publicly available and de-identified database.

\section{RESULTS}

\section{Patient characteristics}

A sum of 4,516 patients, (3,249 MASCC and 1,267 FASCC), were included in this study with a total duration of 27 years, extending from January 1988 to December 2014. This study encompasses four tumor subtypes 1: basaloid squamous cell carcinoma (BSCC), 2: cloacogenic carcinoma (CC), 3: nonkeratinizing large cell (NLC), and 4: verrucous carcinoma (VC). Table 1 listed the characters of participants and the values were statistically significant for each category $(\mathrm{P}<0.05)$. The age of patients ranged from 17 to 104 years. The mean age (SD) at the time of diagnosis was 62.0(13.5) and 63.8(13.0) years for males and females, respectively. The Caucasian population accounted for the largest proportion followed by AfricanAmerican in both men and women. Over $40 \%$ of patients with MASCC were single (never married) while $44.4 \%$ FASCC patients were married. The patients with MASCC had a high-grade tumor and was detected at an advanced stage. The mean tumor size (SD) was 36.4 (40.2) $\mathrm{mm}$ and 39.4 (47.0) $\mathrm{mm}$ in male and female, respectively ( $\mathrm{P}$ $>0.05$ ). Altogether, we identified four subtypes of ASCC, and the basaloid squamous cell carcinoma was the most common subtype accounting for $42.3 \%$ (males $39.1 \%$, females $43.5 \%$ ) of all cases. Patients undergoing surgical resection, radiotherapy and chemotherapy constituted the $36.1 \%, 82.3 \%$, and $78.2 \%$ in MASCC group, respectively.

\section{Influence of tumor subtype on DSM in MASCC and FASCC}

The Kaplan-Meier and the log-rank test were used to compute the DSMs and assess the difference, respectively. Figure 1 depicts the DSMs by gender and stratified by tumor subtypes. The 5-year DSMs were $24.18 \%, 18.08 \%$ for men and women, respectively. MASCC patients with BSCC and CC have higher DSMs compared to FASCC patients $(\mathrm{P}<0.05)$.

Table 2 enlists the results of univariate and multivariate Cox proportional hazards analyses for the DSM. In the univariate analysis model, all the parameters, including age at the time of diagnosis, sex, race, marital status, primary site, tumor stage and grade, size, surgery, radiotherapy, and chemotherapy, were significantly associated with DSM $(\mathrm{P}<0.05)$. In the Cox regression model, the age at the time of diagnosis, sex, race, primary site, tumor stage and grade, surgery, and chemotherapy were statistically significant $(\mathrm{P}<0.05)$. The age at diagnosis $(\mathrm{HR}=1.016(1.005,1.027))$, male $(\mathrm{HR}=1.613(1.227,2.120))$, Afro-American $(\mathrm{HR}=1.793$ $(1.184,2.716))$, tumor stage ( regional, $\mathrm{HR}=2.382(1.779$, 3.189); distant, $\mathrm{HR}=6.815(4.880,9.518))$, high tumor grade $(\mathrm{HR}=1.442(1.075,1.934))$, no surgery $(\mathrm{HR}=$ $1.310(1.003,1.712))$, and no chemotherapy $(\mathrm{HR}=1.971$ $(1.359,2.859))$.

After the five years follow-up, the death proportion caused by ASCC in males and females are $24.18 \%$, $18.08 \%$, respectively. Table 3 established the distribution of DSM analysis for MASCC and FASCC subgroups. Based on tumor subtype, the univariate analysis of DSM displayed significant variation between MASCC and FASCC. Higher DSMs were observed in males with BSCC (5-year DSM: 24.31\%) and CC (5-year DSM: 30.46\%) compared to the female patients (log-rank $\mathrm{P}<0.05)$. In the multivariate analysis, we also observed statistically significant differences between men and women in BSCC $(\mathrm{HR}=2.089(1.325,3.295))$ and $\mathrm{CC}(\mathrm{HR}=1.674(1.218$, 2.301)) subtypes. Moreover, these two tumor subtypes were recognized as the independent hazard indicators for poor survival in males $(\mathrm{P}<0.05)$.

\section{DISCUSSION}

ASCC is rare tumor and is related to HPV, cigarette smoking, and immunosuppression [8-11]. ASCC and cervical carcinoma share several biological characteristics, such as the histopathologic appearance and association with HPV infection, but screening guidelines for ASCC are still unavailable $[1,12-14]$. However, there is distinct variation in incidence rate and prognosis between 
Table 1: Characteristics of patients with anus squamous cell carcinoma

\begin{tabular}{|c|c|c|c|}
\hline \multirow{2}{*}{ Variables } & Female & Male & \multirow{2}{*}{ P value } \\
\hline & $\mathrm{N}=3,249(\%)$ & $\mathrm{N}=1,267(\%)$ & \\
\hline Follow-up time, months & $69.5 \pm 63.1$ & $61.2 \pm 59.4$ & $<0.001$ \\
\hline Age at diagnosis, years & & & $<0.001$ \\
\hline$<55$ & $858(26.4)$ & $362(28.6)$ & \\
\hline $55-65$ & $882(27.2)$ & $348(27.4)$ & \\
\hline $65-75$ & $761(23.4))$ & $328(25.9)$ & \\
\hline$\geq 75$ & $748(23.0)$ & $229(18.1)$ & \\
\hline Mean (SD) & $63.8(13.0)$ & $62.0(13.5)$ & \\
\hline Median & 61.0 & 62.0 & \\
\hline Race & & & 0.006 \\
\hline Caucasian & $2894(89.1)$ & $1100(86.8)$ & \\
\hline Afro-American & $234(7.2)$ & $127(10.0)$ & \\
\hline Other $^{\mathrm{a}}$ & $102(3.1)$ & $34(2.7)$ & \\
\hline Unknown & $19(0.6)$ & $6(0.5)$ & \\
\hline Marital status & & & $<0.001$ \\
\hline Married & $1441(44.4)$ & $485(38.3)$ & \\
\hline Unmarried $^{\mathrm{b}}$ & $1215(37.4)$ & $196(15.5)$ & \\
\hline Single (never married) & $429(13.2)$ & $524(41.4)$ & \\
\hline Unknown & $164(5.0)$ & $62(4.9)$ & \\
\hline Primary site & & & 0.001 \\
\hline Anal canal & $1272(39.2)$ & $462(36.5)$ & \\
\hline Cloacogenic zone & $648(19.9)$ & $248(19.6)$ & \\
\hline Overlapping lesion & $511(15.7)$ & $166(13.1)$ & \\
\hline Anus, unspecified & $818(25.2)$ & $391(30.9)$ & \\
\hline Tumor stage & & & 0.112 \\
\hline Localized & $1669(56.4)$ & $645(56.9)$ & \\
\hline Regional & $922(31.1)$ & $324(28.6)$ & \\
\hline Distant & $371(12.5)$ & $165(14.5)$ & \\
\hline Tumor grade & & & 0.006 \\
\hline Low & $949(29.2)$ & $445(35.1)$ & \\
\hline High & $2300(70.8)$ & $822(64.9)$ & \\
\hline Tumor size & & & 0.475 \\
\hline Mean (SD) & $36.4(40.2)$ & $39.4(47.0)$ & \\
\hline Median & 30.0 & 30.0 & \\
\hline Histological type & & & $<0.001$ \\
\hline $\begin{array}{l}\text { Basaloid squamous cell } \\
\text { carcinoma }\end{array}$ & $1414(43.5)$ & $495(39.1)$ & \\
\hline \multirow[t]{2}{*}{ Cloacogenic carcinoma } & $1189(36.6)$ & $437(34.5)$ & \\
\hline & & & (Continued) \\
\hline
\end{tabular}




\begin{tabular}{lccc}
\hline \multirow{2}{*}{ Variables } & Female & Male & P value \\
\cline { 2 - 3 } Large cell, nonkeratinizing & $\mathbf{N = 3 , 2 4 9 ( \% )}$ & $\mathbf{N = 1 , 2 6 7 ( \% )}$ & \\
Verrucous carcinoma & $585(18.0)$ & $132(10.4)$ & $<0.001$ \\
Surgery & $61(1.9)$ & & \\
Yes & & $551(43.5)$ & \\
No & $1173(36.1)$ & $710(56.0)$ & $<0.001$ \\
Unknown & $2060(63.4)$ & $6(0.5)$ & \\
Radiotherapy & $16(0.5)$ & $944(74.5)$ & \\
Yes & & $303(23.9)$ & $<0.001$ \\
No & $2673(82.3)$ & $20(1.6)$ & \\
Unknown & $532(16.4)$ & & \\
Chemotherapy & $44(1.4)$ & $874(69.0)$ & \\
Yes & & $393(31.0)$ & \\
No & $2540(78.2)$ &
\end{tabular}

ancluding Asian/Pacific Islander and American Indian/Alaska Native.

${ }^{b}$ Including separated, divorced and widowed.

MASCC and FASCC. In spite of some epidemiological investigations on MASCC, a limited number of the randomized controlled trial was carried out to demonstrate the biological features of MASCC and its treatment.

In our study, the mean (SD) ages at diagnosis were 57.9 (12.9) and 62.2(12.5) years for males and females, respectively. The result might reflect the prevalence of HIV infection although the data on HIV is missing in our analysis. The data reports that in the United States more than fifty percent of HIV patients are above the age of 50 years and estimated to be more than seventy percent by 2030 [15]. HIV is the most commonly transmitted by sexual route, and these patients are also prone to other sexually acquired infections, including anal HPV. In this population, HIV-associated immune deficiency and infection with high-risk HPV substantially increase the risk for the development of anal carcinoma [16].

Literature reports that the incidence of anal cancer in the homosexual male is higher than cervical cancer in the United States [17, 18]. To the best of our knowledge, the incidence rate of cervical cancer has declined during the past decades which could be attributed to the widespread implementation of the screening test, like Papanicolaou smear testing, while on the contrary, no routine test is being employed to screen for ACSS. Liszewski et al. [19] recommended the use of Papanicolaou smear testing for screening anal cancer, especially in the high-risk individuals.

A meta-analysis reports the detection of HPV infection in more than $80 \%$ of ASCC specimens [20]. The prevalence of HPV in the two major subtypes of ASCC, basaloid and large cell SCC, is similar [21]. In contrast to HPV-16 in cervical cancer, HPV-18 is prevalent in anal carcinoma $[20,22]$. Tobacco smoking has been reported to increase the risk of infection with HIV, HPV, and also anal cancer $[10,23,24]$, which is possibly due to carcinogenic and immunosuppressive effect [25].

Men who have sex with men, either HIV-positive or immunosuppressed, are at the increased risk of developing ASCC, and the incidence is progressing in this population [26-30]. Shiels et al. [31] declared that the prevalence of HIV in men was the prime cause of increased incidence of ASCC. However, HIV infection may not be a significant contributor for poor prognosis in MASCC patients compared to FASCC. In a retrospective analysis, Wieghard et al. [32] reported that there was no significant difference in recurrence rate and OS between HIV-positive (all male) and HIV-negative anal cancer patients.

Furthermore, we find out that over $40 \%$ of patients were single men, which may result in higher risk of developing ASCC. In male population, a history of being sexually active with a male was associated with anal carcinoma. Moreover, a case series proposed in cancer registry data that there is a higher incidence of anal cancer in single (never-married) than married men $[33,34]$ and also confirmed the increased risk for the development of ASCC in males in case-control studies [8-10, 35, 36]. All the studies on men who have sex with men pointed out the anal intercourse is the most important risk factor for ASCC development $[9,10,35,36]$.

From the genetic perspective, there is a low probability of Kirsten-ras (K-ras) and epidermal growth 
factor receptor (EGFR) mutations in ASCC, which raises the possibility for the therapeutic use of EGFR inhibitors such as Cetuximab in ASCC management [37]. The EGFR (HER-1 or ErbB1), a member of the tyrosine kinase receptor family, is well-known to
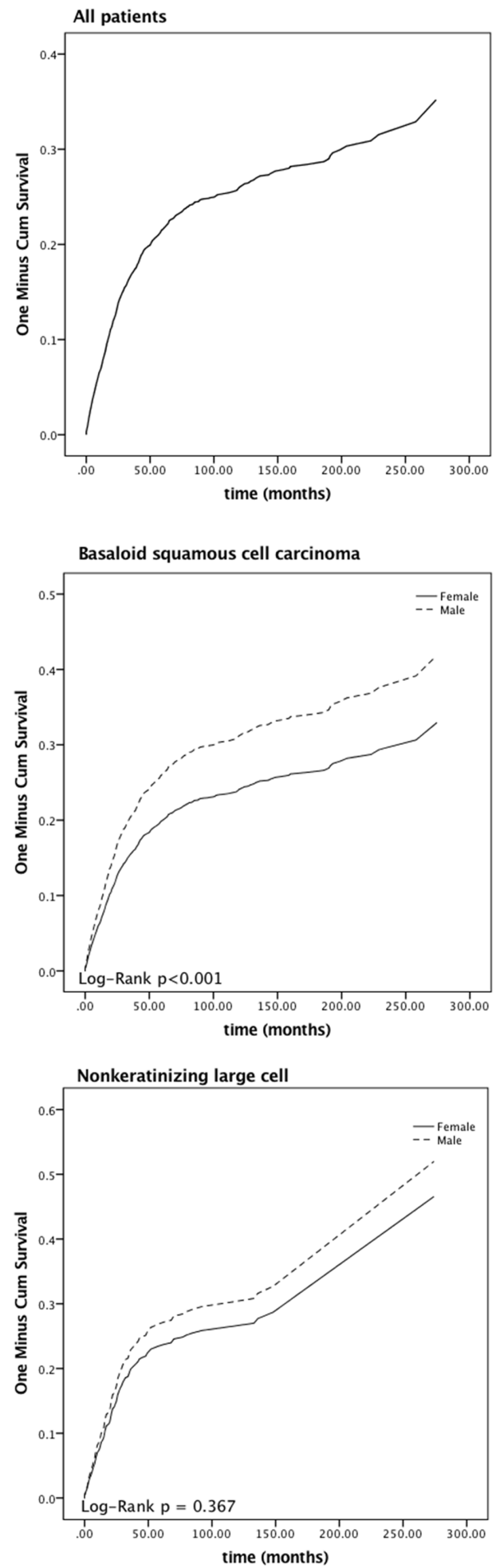

stimulate tumor development via autocrine loop [38]. EGFR overexpression is related to poor prognosis, increased risk of tumor relapse, relative tolerance to treatment, and distant metastasis [39]. Literature reports that overexpression of EGFR in more than $90 \%$ of ASCC
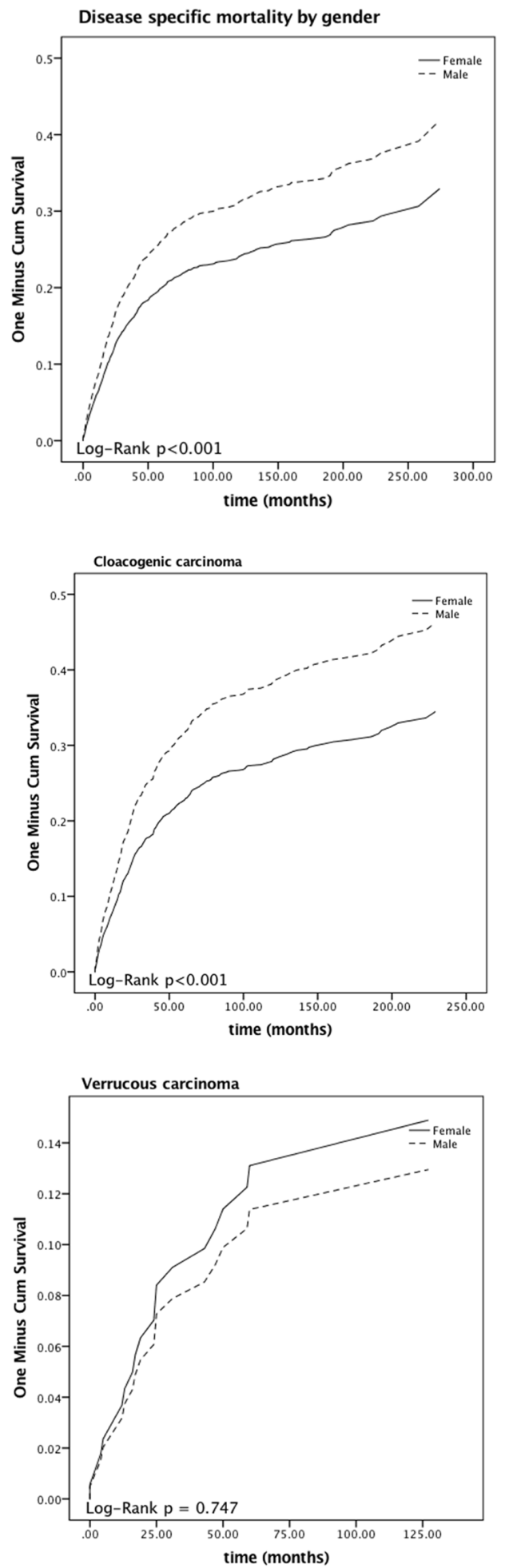

Figure 1: Disease-specific mortality curves of male paired with female anal squamous cell carcinoma patients. 
Table 2: Cox proportional hazards regression model analyses of disease-specific mortality

\begin{tabular}{|c|c|c|c|c|}
\hline \multirow{2}{*}{ Variables } & \multicolumn{2}{|c|}{ Univariate analysis } & \multicolumn{2}{|c|}{ Multivariate analysis ${ }^{\mathrm{a}}$} \\
\hline & HR(95\%CI) & $P$ value & HR(95\%CI) & P value \\
\hline Age at diagnosis, years & $1.018(1.012,1.023)$ & $<0.001$ & $1.016(1.005,1.027)$ & 0.004 \\
\hline \multicolumn{5}{|l|}{ Sex } \\
\hline Female & Reference & & Reference & \\
\hline Male & $1.358(1.181,1.560)$ & $<0.001$ & $1.613(1.227,2.120)$ & 0.001 \\
\hline \multicolumn{5}{|l|}{ Race } \\
\hline Caucasian & Reference & & Reference & \\
\hline Afro-American & $1.583(1.283,1.953)$ & $<0.001$ & $1.793(1.184,2.716)$ & 0.006 \\
\hline Other $^{\mathrm{b}}$ & $1.279(0.908,1.804)$ & 0.160 & $1.031(0.525,2.022)$ & 0.930 \\
\hline \multicolumn{5}{|l|}{ Marital status } \\
\hline Married & Reference & & Reference & \\
\hline Unmarried $^{c}$ & $1.591(1.366,1.853)$ & $<0.001$ & $1.295(0.966,1.737)$ & 0.084 \\
\hline Single(never married) & $1.387(1.165,1.653)$ & $<0.001$ & $1.173(0.841,1.635)$ & 0.349 \\
\hline \multicolumn{5}{|l|}{ Primary site } \\
\hline Anal canal & Reference & & Reference & \\
\hline Cloacogenic zone & $1.306(1.102,1.547)$ & 0.002 & $1.101(0.792,1.532)$ & 0.566 \\
\hline Overlapping lesion & $1.323(1.092,1.603)$ & 0.004 & $1.243(0.888,1.740)$ & 0.204 \\
\hline Anus, unspecified & $1.248(0.741,1.057)$ & 0.179 & $0.931(0.665,1.305)$ & 0.680 \\
\hline \multicolumn{5}{|l|}{ Tumor stage } \\
\hline Localized & Reference & & Reference & \\
\hline Regional & $2.388(2.024,2.817)$ & $<0.001$ & $2.382(1.779,3.189)$ & $<0.001$ \\
\hline Distant & $7.234(6.063,8.632)$ & $<0.001$ & $6.815(4.880,9.518)$ & $<0.001$ \\
\hline \multicolumn{5}{|l|}{ Tumor grade } \\
\hline Low & Reference & & Reference & \\
\hline High & $1.386(1.125,1.706)$ & 0.002 & $1.442(1.075,1.934)$ & 0.015 \\
\hline Tumor size & $1.003(1.002,1.004)$ & $<0.001$ & $1.000(0.998,1.001)$ & 0.869 \\
\hline \multicolumn{5}{|l|}{ Surgery } \\
\hline Yes & Reference & & Reference & \\
\hline No & $1.435(1.248,1.649)$ & $<0.001$ & $1.310(1.003,1.712)$ & 0.047 \\
\hline \multicolumn{5}{|l|}{ Radiotherapy } \\
\hline Yes & Reference & & Reference & \\
\hline No & $1.368(1.166,1.606)$ & $<0.001$ & $0.987(0.662,1.472)$ & 0.951 \\
\hline \multicolumn{5}{|l|}{ Chemotherapy } \\
\hline Yes & Reference & & Reference & \\
\hline No & $1.472(1.275,1.699)$ & $<0.001$ & $1.971(1.359,2.859)$ & $<0.001$ \\
\hline
\end{tabular}

${ }^{a}$ Adjusted for age at diagnosis, sex, race, marital status, site, tumor stage, tumor grade, size, surgery, radiotherapy and chemotherapy.

b'Including Asian/Pacific Islander and American Indian/Alaska Native.

'Including separated, divorced and widowed.

Reference group for each model was "females." cHR: crude hazard ratio; CI: confidence interval; aHR: adjusted hazard ratio (adjusted for age at diagnosis, sex, race, marital status, primary site, tumor stage, grade, tumor size and treatment modalities). 
Table 3: Disease-specific mortality according to tumor subtypes between MASCC and FASCC

\begin{tabular}{|c|c|c|c|c|c|c|}
\hline \multirow{2}{*}{ Tumor subtype } & \multicolumn{2}{|c|}{ 5-year DSM (\%) } & \multirow{2}{*}{$\operatorname{cHR}(95 \% \mathrm{CI})$} & \multirow{2}{*}{ P value } & \multirow{2}{*}{$\operatorname{aHR}(95 \% \mathrm{CI})$} & \multirow{2}{*}{ Pvalue } \\
\hline & Female & Male & & & & \\
\hline $\begin{array}{l}\text { Basaloid squamous } \\
\text { cell carcinoma }\end{array}$ & 16.54 & 24.31 & $1.663(1.308,2.114)$ & $<0.001$ & $2.089(1.325,3.295)$ & 0.002 \\
\hline Cloacogenic carcinoma & 23.17 & 30.46 & $1.470(1.198,1.803)$ & $<0.001$ & $1.674(1.218,2.301)$ & 0.001 \\
\hline $\begin{array}{l}\text { Large cell, } \\
\text { nonkeratinizing }\end{array}$ & 24.01 & 25.75 & $1.171(0.830,1.650)$ & 0.369 & $1.160(0.632,2.131)$ & 0.632 \\
\hline Verrucous carcinoma & 14.19 & 10.90 & $0.860(0.343,2.156)$ & 0.748 & $0.026(0.001,4.244)$ & 0.984 \\
\hline
\end{tabular}

Reference group for each model was "female". cHR: crude hazard ratio; CI: confidence interval; aHR: adjusted hazard ratio (adjusted for age at diagnosis, sex, race, marital status, site, tumor stage, tumor grade, size, surgery, radiotherapy and chemotherapy).

Reference group for each model was "females." cHR: crude hazard ratio; CI: confidence interval; aHR: adjusted hazard ratio (adjusted for age at diagnosis, sex, race, marital status, primary site, tumor stage, grade, tumor size and treatment modalities).

[37, 40-45]. However, there is not enough evidence of comparison of EGFR overexpression in between sexes, which requires further investigation.

We noticed a significant difference in between genders for basaloid squamous cell carcinoma (BSCC) subtype. In relation to that, literature reports the triplenegative immunophenotype, (estrogen receptor (-), progesterone receptor (-), and human epidermal growth factor receptor $2(-))$, and the expression of cytokeratin (CK), including CK5, CK14 or CK17, are considered as the gold standard for the diagnosis of BSCC [4648]. Multiple studies have reported the poor of triplenegative carcinoma in comparison to other subtypes, especially in male patients [46, 49-51]. Foulkes and Turner et al. $[52,53]$ reported the association of BSCC carcinoma with BRCA1 germline, which suggests that anal BSCC carcinoma could be sensitive to platinumbased chemotherapy rather than mitomycin $\mathrm{C}$ because BRCA1 mutant carriers typically have somatic cell loss of the remaining BRCA1 allele and characterized by defects in double strand breaks DNA repair [54]. Reasonably, the difference in homologous gene mutations in tumor subtypes may contribute to the diagnosis and treatment of anal BSCC carcinoma.

Although the survival rate between genders varies significantly according to the histological subtypes, the confounding effect of other types of carcinomas was inevitable due to the restricted categorization. It was reported that about $30 \%$ of ASCC patients responded poor to chemoradiotherapy for unexplained reasons, and Graham et al. [55] discovered 10 in 37 samples primitively classified as BSCC were misdiagnosed, including basal cell carcinoma $(n=6)$, melanoma $(n=2)$, and neuroendocrine carcinoma $(\mathrm{n}=2)$ and a female predominance was also noticed in the final BSCC group. A precise classification system is in need despite the fact that WHO recommends using the term "squamous carcinoma" to cover all pathological types of ASCC.

Moreover, we noticed the decreased rate of survival for men with CC and NLC subtype. In a retrospective analysis, Serota et al. [56] report the frequent occurrence of CC in women, while men were reported with more glandular variations of $\mathrm{CC}$, early metastasis to lymphoid follicles and other organs and decreased survival compared to women. It is quite challenging to distinguish $\mathrm{CC}$ from other ASCCs owing to same clinical behavior, and the standard of care $[57,58]$. Unfortunately, in recent years, no consistent study compared the prognosis of patients with NLC to the other ASCCs. However, we observed an apparent difference in survival in between genders in the NLC subgroup.

With regards to the limitations of our study, we were unable to assess molecular indicators, such as EGFR which could lead to the early diagnosis and anticipate the prognosis. Moreover, the conclusions derived from retrospective studies were of a low methodological grade in contrast to the randomized controlled trials. Furthermore, due to the anonymous rule in the SEER program, we were unable to contact the patients for detailed information. Finally, information regarding comorbidities and tumor relapse is not documented in the database.

\section{MATERIALS AND METHODS}

\section{Data source and study design}

We used the SEER program database (Incidence - SEER 18 Regs Research Data + Hurricane Katrina Impacted Louisiana Cases, Nov 2016 Sub, 1988-2014 
varying) to acquire data of patients diagnosed with ASCC from January 1988 to December 2014. Histologic International Classification of Diseases (ICD) codes, third edition (ICD-0-3) were undertaken to identify squamous cell carcinoma (8050/3-8053/3, 8070/3-8076/3, 8083/3, $8084 / 3,8123 / 3,8124 / 3)$. Anatomic codes (C21.0-C21.2, $\mathrm{C} 21.8)$ were employed to screen for neoplasm originating in the anus. The data was extracted from the SEER database for analysis, including age at diagnosis, sex, marital status, race, primary site, histological type, tumor size, tumor stage, differentiation, treatment modality, survival status, the cause of death, and survival months. Cases without details on pathological types, samples less than 90 cases, patients diagnosed on autopsy, and the patients who were not confirmed microscopically were excluded from our study. We divided the differentiations into two categories (well-differentiated and moderately differentiated histologic features were defined as low grade, and poorly differentiated and undifferentiated characters were asserted as a high degree). The population was allocated into four groups for the subgroup analysis on the basis of histological types.

\section{Statistical analysis}

The primary result of our investigation was disease-specific mortality (DSM). All the variables were statistically characterized. DSW was computed by the Kaplan-Meier method, and the log-rank test was applied to examine the difference. We figured hazard ratios (HRs) and the 95\% confidence interval (CI) using the Cox proportional hazards model. The multivariate Cox proportional hazards model was performed to calculate the mortality-association risk factors in patients with ASCC after adjusting for other variables. We used multiple imputation by Monte Carlo Markov Chain method to estimate missing values. SEER*Stat version 8.3.4 (IMS Inc, USA) was used to extract data. SPSS version 23 (IBM Corp, USA) was used to accomplish all the statistical analyses. The $\mathrm{R}$ statistical software version 3.3.1 (www.r-project.org) was employed to perform multiple-imputation. Differences between the groups were considered statistically significant if the $\mathrm{P}$ values were less than 0.05 .

\section{Ethical statements}

The National Cancer Institute and the Ethics Review Board of Zhongnan Hospital of Wuhan University found that the institutional review board approval is not required for the SEER study as it utilizes the unidentified publicuse database.

\section{CONCLUSION}

To sum up, the SEER program database is of significant advantage despite these restrictions and provides feasibility for researching huge population with rare cancers. We report noticeable differences between MASCC and FASCC DSM in various subtypes. Further studies are required to for the precise classification of ASCC and individualized management of MASCC.

\section{Abbreviations}

MASCC: male anal squamous cell carcinoma; FASCC: female anal squamous cell carcinoma; DSM: disease-specific mortality; ASCC: anal squamous cell carcinomas; BSCC: basal squamous cell carcinoma; $\mathrm{CC}$ : cloacogenic carcinoma; VC: verrucous carcinoma; NLC: nonkeratinizing large cell.

\section{Author contributions}

Conceptualization: Zihao Wan, Zhihao Huang, Liaobin Chen, Jingfeng Li.

Data curation: Zihao Wan, Zhihao Huang.

Formal analysis: Zihao Wan, Zhihao Huang, Jingfeng Li.

Investigation: Zihao Wan, Zhihao Huang, Vikash Vikash, Liaobin Chen, Jingfeng Li.

Methodology: Zihao Wan, Zhihao Huang.

Project administration: Liaobin Chen, Jingfeng Li.

Supervision: Zihao Wan, Liaobin Chen, Jingfeng Li.

Validation: Zihao Wan, Zhihao Huang, Vikash Vikash, Kelash Rai, Sindhu Vikash, Liaobin Chen, Jingfeng Li.

Visualization: Zihao Wan, Zhihao Huang.

Original draft: Zihao Wan, Zhihao Huang, Vikash Vikash.

Review \& editing: Zihao Wan, Zhihao Huang, Vikash Vikash, Kelash Rai, Sindhu Vikash, Liaobin Chen, Jingfeng Li.

\section{CONFLICTS OF INTEREST}

The authors declare no conflicts of interest.

\section{FUNDING}

No external funding was obtained for this research.

\section{REFERENCES}

1. National Cancer Institute. Anal cancer. http://www.cancer. gov/cancertopics/types/anal. 
2. American Cancer Society. Cancer Facts and Figures 2012. http://www.cancer.org/research/cancerfactsfigures/ cancerfactsfigures/cancer-facts-figures-2012.

3. Johnson LG, Madeleine MM, Newcomer LM, Schwartz SM, Daling JR. Anal cancer incidence and survival: the surveillance, epidemiology, and end results experience, 1973-2000. Cancer. 2004; 101:281-288.

4. Julie DR, Goodman KA. Advances in the Management of Anal Cancer. Curr Oncol Rep. 2016; 18:20.

5. Jin F, Stein AN, Conway EL, Regan DG, Law M, Brotherton JM, Hocking J, Grulich AE. Trends in anal cancer in Australia, 1982-2005. Vaccine. 2011; 29:2322-2327.

6. Soeberg MJ, Rogers K, Currow DC, Young JM. Trends in incidence and survival for anal cancer in New South Wales, Australia, 1972-2009. Cancer Epidemiol. 2015; 39:842-847.

7. Kim E, Kim JS, Choi M, Thomas CR Jr. Conditional survival in anal carcinoma using the national populationbased survey of epidemiology and end results database (1988-2012). Dis Colon Rectum. 2016; 59:291-298.

8. Frisch M, Glimelius B, van den Brule AJ, Wohlfahrt J, Meijer CJ, Walboomers JM, Goldman S, Svensson C, Adami HO, Melbye M. Sexually transmitted infection as a cause of anal cancer. N Engl J Med. 1997; 337:1350-1358.

9. Daling JR, Weiss NS, Hislop TG, Maden C, Coates RJ, Sherman KJ, Ashley RL, Beagrie M, Ryan JA, Corey L. Sexual practices, sexually transmitted diseases, and the incidence of anal cancer. N Engl J Med. 1987; 317:973-977.

10. Daling JR, Madeleine MM, Johnson LG, Schwartz SM, Shera KA, Wurscher MA, Carter JJ, Porter PL, Galloway DA, McDougall JK. Human papillomavirus, smoking, and sexual practices in the etiology of anal cancer. Cancer. 2004; 101:270-280.

11. Denny LA, Franceschi S, de Sanjose S, Heard I, Moscicki AB, Palefsky J. Human papillomavirus, human immunodeficiency virus and immunosuppression. Vaccine. 2012; 30:F168-174.

12. Palefsky JM, Holly EA, Gonzales J, Berline J, Ahn DK, Greenspan JS. Detection of human papillomavirus DNA in anal intraepithelial neoplasia and anal cancer. Cancer Res. 1991; 51:1014-1019.

13. Zaki SR, Judd R, Coffield LM, Greer P, Rolston F, Evatt BL. Human papillomavirus infection and anal carcinoma. Retrospective analysis by in situ hybridization and the polymerase chain reaction. Am J Pathol. 1992; 140:1345-1355.

14. Melbye M, Sprogel P. Aetiological parallel between anal cancer and cervical cancer. Lancet. 1991; 338:657-659.

15. Wing EJ. HIV and aging. Int J Infect Dis. 2016; 53:61-68.

16. Grulich AE, van Leeuwen MT, Falster MO, Vajdic CM. Incidence of cancers in people with HIV/AIDS compared with immunosuppressed transplant recipients: a metaanalysis. Lancet. 2007; 370:59-67.
17. Goedert JJ, Cote TR, Virgo P, Scoppa SM, Kingma DW, Gail MH, Jaffe ES, Biggar RJ. Spectrum of AIDS-associated malignant disorders. Lancet. 1998; 351:1833-1839.

18. Jemal A, Murray T, Samuels A, Ghafoor A, Ward E, Thun MJ. Cancer statistics, 2003. CA Cancer J Clin. 2003; 53:5-26.

19. Liszewski W, Ananth AT, Ploch LE, Rogers NE. Anal Pap smears and anal cancer: what dermatologists should know. J Am Acad Dermatol. 2014; 71:985-992.

20. De Vuyst H, Clifford GM, Nascimento MC, Madeleine MM, Franceschi S. Prevalence and type distribution of human papillomavirus in carcinoma and intraepithelial neoplasia of the vulva, vagina and anus: a meta-analysis. Int J Cancer. 2009; 124:1626-1636.

21. Grulich AE, Poynten IM, Machalek DA, Jin F, Templeton DJ, Hillman RJ. The epidemiology of anal cancer. Sex Health. 2012; 9:504-508.

22. Hoots BE, Palefsky JM, Pimenta JM, Smith JS. Human papillomavirus type distribution in anal cancer and anal intraepithelial lesions. Int J Cancer. 2009; 124:2375-2383.

23. Frisch M, Glimelius B, Wohlfahrt J, Adami HO, Melbye M. Tobacco smoking as a risk factor in anal carcinoma: an antiestrogenic mechanism? J Natl Cancer Inst. 1999; 91:708-715.

24. Linam JM, Chand RR, Broudy VC, Liu KC, Back AL, Lin EH, Patel SA. Evaluation of the impact of HIV serostatus, tobacco smoking and CD4 counts on epidermoid anal cancer survival. Int J STD AIDS. 2012; 23:77-82.

25. Appleby P, Beral V, Berrington de Gonzalez A, Colin D, Franceschi S, Goodill A, Green J, Peto J, Plummer M, Sweetland S. Carcinoma of the cervix and tobacco smoking: collaborative reanalysis of individual data on 13,541 women with carcinoma of the cervix and 23,017 women without carcinoma of the cervix from 23 epidemiological studies. Int J Cancer. 2006; 118:1481-1495.

26. Mendez-Martinez R, Rivera-Martinez NE, CrabtreeRamirez B, Sierra-Madero JG, Caro-Vega Y, Galvan $\mathrm{SC}$, de Leon DC, Garcia-Carranca A. Multiple human papillomavirus infections are highly prevalent in the anal canal of human immunodeficiency virus-positive men who have sex with men. BMC Infect Dis. 2014; 14:671.

27. Chin-Hong PV, Vittinghoff E, Cranston RD, Browne L, Buchbinder S, Colfax G, Da Costa M, Darragh T, Benet DJ, Judson F, Koblin B, Mayer KH, Palefsky JM. Age-related prevalence of anal cancer precursors in homosexual men: the EXPLORE study. J Natl Cancer Inst. 2005; 97:896-905.

28. Machalek DA, Poynten M, Jin F, Fairley CK, Farnsworth A, Garland SM, Hillman RJ, Petoumenos K, Roberts J, Tabrizi SN, Templeton DJ, Grulich AE. Anal human papillomavirus infection and associated neoplastic lesions in men who have sex with men: a systematic review and meta-analysis. Lancet Oncol. 2012; 13:487-500. 
29. Patel P, Hanson DL, Sullivan PS, Novak RM, Moorman AC, Tong TC, Holmberg SD, Brooks JT. Incidence of types of cancer among HIV-infected persons compared with the general population in the United States, 1992-2003. Ann Intern Med. 2008; 148:728-736.

30. Brewster DH, Bhatti LA. Increasing incidence of squamous cell carcinoma of the anus in Scotland, 1975-2002. Br J Cancer. 2006; 95:87-90.

31. Shiels MS, Pfeiffer RM, Chaturvedi AK, Kreimer AR, Engels EA. Impact of the HIV epidemic on the incidence rates of anal cancer in the United States. J Natl Cancer Instit. 2012; 104:1591-1598.

32. Wieghard N, Hart KD, Kelley K, Lu KC, Herzig DO, Mitin T, Thomas CR Jr, Tsikitis VL. HIV positivity and anal cancer outcomes: a single-center experience. Am J Surg. 2016; 211:886-893.

33. Melbye M, Rabkin C, Frisch M, Biggar RJ. Changing patterns of anal cancer incidence in the United States, 19401989. Am J Epidemiol. 1994; 139:772-780.

34. Scholefield JH, Thornton Jones H, Cuzick J, Northover JM. Anal cancer and marital status. Br J Cancer. 1990; 62:286-288.

35. Holly EA, Whittemore AS, Aston DA, Ahn DK, Nickoloff BJ, Kristiansen JJ. Anal cancer incidence: genital warts, anal fissure or fistula, hemorrhoids, and smoking. J Natl Cancer Instit. 1989; 81:1726-1731.

36. Tseng HF, Morgenstern H, Mack TM, Peters RK. Risk factors for anal cancer: results of a population-based casecontrol study. Cancer Causes Control. 2003; 14:837-846.

37. Paliga A, Onerheim R, Gologan A, Chong G, Spatz A, Niazi T, Garant A, Macheto D, Alcindor T, Vuong T. EGFR and K-ras gene mutation status in squamous cell anal carcinoma: a role for concurrent radiation and EGFR inhibitors? Br J Cancer. 2012; 107:1864-1868.

38. Matczak E. Human papillomavirus infection: an emerging problem in anal and other squamous cell cancers. Gastroenterology. 2001; 120:1046-1048.

39. Herbst RS, Onn A, Mendelsohn J. The role of growth factor signaling in malignancy. Cancer treatment and research. 2003; 115:19-72.

40. Alvarez G, Perry A, Tan BR, Wang HL. Expression of epidermal growth factor receptor in squamous cell carcinomas of the anal canal is independent of gene amplification. Mod Pathol. 2006; 19:942-949.

41. Ajani JA, Wang X, Izzo JG, Crane CH, Eng C, Skibber JM, Das P, Rashid A. Molecular biomarkers correlate with disease-free survival in patients with anal canal carcinoma treated with chemoradiation. Dig Dis Sci. 2010; 55:1098-1105.

42. Van Damme N, Deron P, Van Roy N, Demetter P, Bols A, Van Dorpe J, Baert F, Van Laethem JL, Speleman F, Pauwels P, Peeters M. Epidermal growth factor receptor and K-RAS status in two cohorts of squamous cell carcinomas. BMC Cancer. 2010; 10:189.
43. Zampino MG, Magni E, Sonzogni A, Renne G. K-ras status in squamous cell anal carcinoma (SCC): it's time for targetoriented treatment? Cancer Chemother Pharmacol. 2009; 65:197-199.

44. Gilbert DC, Williams A, Allan K, Stokoe J, Jackson T, Linsdall S, Bailey CM, Summers J. p16INK4A, p53, EGFR expression and KRAS mutation status in squamous cell cancers of the anus: correlation with outcomes following chemo-radiotherapy. Radiother Oncol. 2013; 109:146-151.

45. Le LH, Chetty R, Moore MJ. Epidermal growth factor receptor expression in anal canal carcinoma. Am J Clin Pathol. 2005; 124:20-23.

46. Nielsen TO, Hsu FD, Jensen K, Cheang M, Karaca G, Hu Z, Hernandez-Boussard T, Livasy C, Cowan D, Dressler L, Akslen LA, Ragaz J, Gown AM, et al. Immunohistochemical and clinical characterization of the basal-like subtype of invasive breast carcinoma. Clin Cancer Res. 2004; 10:5367-5374.

47. Micello D, Marando A, Sahnane N, Riva C, Capella C, Sessa F. Androgen receptor is frequently expressed in HER2-positive, ER/PR-negative breast cancers. Virchows Arch. 2010; 457:467-476.

48. Kim MJ, Ro JY, Ahn SH, Kim HH, Kim SB, Gong G. Clinicopathologic significance of the basal-like subtype of breast cancer: a comparison with hormone receptor and Her2/neu-overexpressing phenotypes. Human Pathol. 2006; 37:1217-1226.

49. Perou CM, Sorlie T, Eisen MB, van de Rijn M, Jeffrey SS, Rees CA, Pollack JR, Ross DT, Johnsen H, Akslen LA, Fluge O, Pergamenschikov A, Williams C, et al. Molecular portraits of human breast tumours. Nature. 2000; 406:747-752.

50. Wu Q, Li J, Zhu S, Wu J, Li X, Liu Q, Wei W, Sun S. Poorer breast cancer survival outcomes in males than females might be attributable to tumor subtype. Oncotarget. 2016; 7:87532-87542. https://doi.org/10.18632/oncotarget.12052.

51. Carey LA, Perou CM, Livasy CA, Dressler LG, Cowan D, Conway K, Karaca G, Troester MA, Tse CK, Edmiston S, Deming SL, Geradts J, Cheang MC, et al. Race, breast cancer subtypes, and survival in the Carolina Breast Cancer Study. JAMA. 2006; 295:2492-2502.

52. Foulkes WD, Stefansson IM, Chappuis PO, Begin LR, Goffin JR, Wong N, Trudel M, Akslen LA. Germline BRCA1 mutations and a basal epithelial phenotype in breast cancer. J Natl Cancer Inst. 2003; 95:1482-1485.

53. Turner NC, Reis-Filho JS, Russell AM, Springall RJ, Ryder K, Steele D, Savage K, Gillett CE, Schmitt FC, Ashworth A, Tutt AN. BRCA1 dysfunction in sporadic basal-like breast cancer. Oncogene. 2007; 26:2126-2132.

54. Imyanitov EN, Moiseyenko VM. Drug therapy for hereditary cancers. Hered Cancer Clin Pract. 2011; 9:5.

55. Graham RP, Arnold CA, Naini BV, Lam-Himlin DM. Basaloid squamous cell carcinoma of the anus revisited. Am J Surg Pathol. 2016; 40:354-360. 
56. Serota AI, Weil M, Williams RA, Wollman JS, Wilson SE. Anal cloacogenic carcinoma: classification and clinical behavior. Arch Surg. 1981; 116:456-459.

57. Bertani E, Chiappa A, Mazzarol G, Contino G, Lazzari R, Zampino MG, Viale G, Andreoni B. Aggressive treatment approach for cloacogenic carcinoma of the anorectum: report from a single cancer center. Dig Surg. 2010; 27:297-301.
58. Bartelink H, Roelofsen F, Eschwege F, Rougier P, Bosset JF, Gonzalez DG, Peiffert D, van Glabbeke M, Pierart M. Concomitant radiotherapy and chemotherapy is superior to radiotherapy alone in the treatment of locally advanced anal cancer: results of a phase III randomized trial of the European Organization for Research and Treatment of Cancer Radiotherapy and Gastrointestinal Cooperative Groups. J Clin Oncol. 1997; 15:2040-2049. 